\title{
NUMERICAL AND EXPERIMENTAL MODELING OF THE STATIC RESPONSE OF SIMPLY SUPPORTED THIN-WALLED BOX GIRDER BRIDGES
}

\author{
G. C.Ezeokpube ${ }^{1,}$, S. B Singh ${ }^{2}$ and N. N., Osadebe ${ }^{3}$ \\ 1DEPT OF CiVIL ENGINEERING, MichaEl OKPARA UNIVERSITY OF AGRICULTURE UMUDiKe, ABIA STATE. NIGERIA \\ 2DEPARTMENT OF CIVIL ENGINEERING., BIRLA INSTITUTE OF TECHNOLOGY AND SCIENCE, INDIA \\ 3DEPARTMENT OF CIVIL ENGINEERING, UNIVERSITY OF NigeRIA NSUKKA, ENUGU STATE. NIGERIA \\ Email addresses.1 engrgreg2006@yahoo.com, ${ }^{2}$ sbsinghbits@gmail.comand,3mkemamaka@yahoo.com
}

\begin{abstract}
This paper presents numerical and experimental modeling of the static response of simply supported thin-walled reinforced concrete box girder bridges. The work is executed to verify the validity of software developed by the authors for the finite strip analysis of continuous thin-walled box girder bridges and also to observe the effect of flange width on the static response of these type of structural elements under service load from experimental and numerical studies. The laboratory load/deformation relationship is presented in the form of deflection ratios that is displayed alongside the finite strip analysis results of the same loading condition. The results obtained from the laboratory experiment and the software showed very good agreement and are, averagely, $21.5 \%$ and $19.5 \%$ higher than that of the beam theory solution respectively. Verification of the software with published solutions is also conducted. The results from the developed software showed very good agreement with literature in terms of deflection and stress distributions. These results suggest that the effect of shear deformation, which is more significant on deflection than on stresses, increases with increase in flange width and that the developed software is capable of capturing the general behavior of thin-walled box girder bridges.
\end{abstract}

Keywords: model experiment; numerical analysis; flat shell strips; and reinforced concrete thin-walled sections.

\section{INTRODUCTION}

The main objective of experimental studies in thinwalled box girder bridges is to examine the validity of theoretical formulations, computer programs, existing methods of elastic analysis and to investigate the behavior of box girder bridges Sennah and Keneddy [1]. Few experimental investigations in box girder bridges have been conducted in comparison to the numerous analytical studies Kulicki [2]. In addition many of the experimental studies focused on laboratory tests while few authors Huang, Huang and Huang et al.[3, 4, 5] have reported on field testing of existing box girder bridges.

The first objective of this work is to conduct experiment to determine the effect of flange with on the static response of thin-walled reinforced concrete box girder bridges under service load and compare the obtained results with that of a software developed by the authors for the same loading conditions. The second objective is to verify the developed software with published solutions. The third objective is to compare experimental results and that of the developed software with the beam theory solutions. Based on the numerical and experimental results, the final objective of this work is to develop recommendation for subsequent experiments and analysis of these types of structural elements.

In this paper a report of numerical and experimental modeling of the static response of thin-walled reinforced concrete box girder bridges is given. The work is executed to verify the validity of a software developed by the authors for the finite strip analysis of continuous thin-walled box girder bridges and also to observe the effect of flange width on the static response of these type of structural elements under service load from experimental and numerical studies. The model experiment is conducted to the study of the effect of flange width on the static response of thinwalled reinforced concrete box girder bridges under service loads. The experimental results obtained are 
compared with those of analysis of the same loading conditions, which are obtained by the application of a software written in MATLAB mode by Ezeokpube [9] for the finite strip analysis of continuous thin-walled box girder bridges. Flat shell strips for continuous structures are used in the finite strip formulations of the developed software. To further test its validity, the developed software is used to determine the static response of a simply supported thin-walled reinforced concrete box girder bridge subjected to eight point loads, whose analysis results were previously presented by Cheung et al. [7]. The results obtained with the software are compared to those obtained by Cheung et al. [7].Since the result of the experiment and that of the finite strip method will naturally include the effects of shear deformation, it is also important to compare these results with that of the beam theory solution which does not include the effects of shear deformation. Therefore, the beam theory solution is used as the benchmark.

\section{BACKGROUND OF STUDY}

The basic background information in this work focus on the following: I) previous studies on experimental and numerical modeling of box girder bridges; II) developments on the thin-walled cross-section theory which is the basis for choosing dimensions of specimen in experimental studies of such structural elements; and III) service loads and deflection ratio.

\subsection{Previous Studies}

Among previous studies, Nakai et. al. [8] tested four Plexiglas, box-girder models of the same span length, radius of curvature, and central angle but with different numbers of intermediate diaphragms to verify the results obtained from thin-walled beam theory. Shanmugam and Balendra [9] conducted experimental studies on the elastic behavior of two, Perspex, multi-cell bridge models - one with solid webs and the other with web openings. Results from analytical solution, using the grillage technique and the finite element method, compared favorable with the experimental values for deflections and flangeedge stresses. Shanmugam and Balendra [10] tested elastically two, Perspex, cellular models of different span-to-radius ratios subjected to different loading conditions to examine the results obtained from a finite-element modeling.

Lou et. al. [11] investigated the shear lag phenomenon of box girders using three Perspex glass models. The experiments addressed two issues, the beam-column action and the effect of varying depth upon the shear lag of box girders. In general the experimental results match reasonably well with the numerical predictions. However, there are noticeable differences. In some cases, the differences in the stress predicted by the finite element method and the experimental results can be as high as $25 \%$. Luo et al. [12] developed a finite segment model to calculate the shear lag effects for box girders with varying depth. Multiple longitudinal displacement functions were used to derive the stiffness matrix and the nodal force vector of the segment element. The shear deformation of the web was taken into consideration. A Perspex glass model of a three-span continuous box girder with varying depth was tested to verify the validity of the proposed method.

Huang [4] conducted full scale field tests and analysis on the Veteran's Memorial curved steel-box Girder Bridge. Tests and analytical results show, among other things, that the current AASHTO guide specifications regarding the first transverse stiffener spacing at the simple end support of a curved girder may be too conservative for bridge load capacity rating. Zhang et al. [13] proposed a new type of streamline girder (lenticular cross-section) bridge with a thin-walled steel box girder. The aim of the study was to investigate the effect of shear lag in thin-walled box girder bridges with large width-to-span ratios through experimental and numerical studies. The simulation of the computation results compared well with the experimental results. Xu et al. [14] carried out experimental study on double composite action in the negative flexural region of two-span continuous composite box girder. Two continuous composite girders were designed to study the mechanical properties in concrete crack, formation of sectional plastic hinge, load-carrying capacity, etc. Results of the analysis indicated that double composite action made concrete crack development slower in service stage.

Hodson et al. [15] carried out a static live-load test of a typical box-girder bridge. Based on the results of the parametric study using the calibrated finite-element modeling scheme, a new equation, which more accurately predicts the exterior girder distribution factor, was proposed. Lu et al. [16] presented a model test of $1 / 30$ scale and numerical finite element analysis (FEA) on the mechanical behavior of a typical composite box girder bridge. The results of the finite element analysis were in good agreement with those of the tests in terms of strength and stiffness. Guo and Chen [17] presented the long-term stress monitoring 
on several fatigue-prone details of Fort Duquesne Bridge, a 40-year old steel bridge built in 1969 across the Allegheny River in Pittsburgh, Pennsylvania. Based on the study a probabilistic fatigue assessment procedure was proposed, which combines the longterm SHM (Structural Health Monitoring) and the LEFM (Linear Elastic Fracture Mechanics). It was conclude that some unique bridge details could be evaluated with regards to their fatigue reliabilities, using the proposed procedure.

\subsection{Developments in Thin-Walled Cross-Section Theory}

In conducting laboratory experiment on thin-walled sections, the criteria for choosing the dimensions of the specimen are governed by the thin-walled crosssection theory which has been excellently outline by Kurian and Menon [18]. They are itemized below:

(I)According to Vlasov's [19] criterion for thin-walled sections:

$$
\begin{gathered}
\frac{\text { Thickness of Web }}{\text { Depth of Web }} \leq \frac{1}{10} \\
\text { and } \frac{\text { Depth of Section }}{\text { Length of Section }} \leq \frac{1}{10}
\end{gathered}
$$

(II) Maisel and Roll [20] revealed that the first criterion $\{$ i.e. (I)\} is usually not satisfied for concrete box girders.

(III) Survey by Swann [21] showed that the most commonly used Single-Cell thin-walled Box Girder Bridge structures, with constant cross section, are rectangular in cross-section with a Width to Depth ratio of around 2 and with flange over hangs.

(IV) Span to Depth ratio of medium sized bridges lies in the range of $13-30$ [18]. Here the larger values correspond to continuous spans and smaller values correspond to simply supported bridges.

(V) In the experimental studies conducted by Rasmussen and Baker [22] on concrete box girders, to develop a thin-walled section that obeys the thin-walled theory, the following ratios were chosen:

$$
\begin{gathered}
\frac{\text { Thickness of Web }}{\text { Depth of Web }}=\frac{1}{7} \\
\text { and } \frac{\text { Thickness of Flange }}{\text { Width of Flange }}=\frac{1}{10}
\end{gathered}
$$

(VI) In the experimental studies by [18] the following ratios were used:

$$
\frac{\text { Thickness of Web }}{\text { Depth of Web }}=\frac{1}{8.3}<\frac{1}{7}
$$

$$
\begin{aligned}
& \frac{\text { Thickness of Flange }}{\text { Width of Flange }}=\frac{1}{15}<\frac{1}{10}, \\
& \frac{\text { Depth of Cross Section }}{\text { Length of Specimen }}=\frac{1}{10.6}<\frac{1}{10}, \\
& \frac{\text { Width }}{\text { Depth }}=1.80 \text { (close to } 2 \text { ) }
\end{aligned}
$$

Hence, the chosen dimensions of their [18] specimen obey the thin-walled cross-section theory and represent a scale of $1 / 5$ in relation to the prototype bridge usually used in practice.

\subsection{Service Loads and Deflection Ratio}

In this work, concentrated loads are applied to the box girder bridge models to represent the effect of wheel loads or service loads. In practice, wheel loading induce concentrated loads on bridge decks. In the immediate vicinity of the point of applications of each of the concentrated loads, response profiles with very high peaks are produced [17]; Loo and Cusens [23]. This is termed local effect. Investigation of local effects is outside the scope of this work. The overall rather than the local behavior of the bridge is the overriding consideration. Such local effect is avoided by using a two point loading system in which the response is recorded at the center of the bridge which is located mid-way between the two concentrated loads.

The structural model is analyzed in order to investigate the maximum response of a simply supported box girder bridge at mid-span. The response result could be given in the form of deflection ratio. Lertsima et al. [24] defined deflection ratio as the ratio of the deflection due to finite element analysis to that due to the beam theory solution. In that case the finite element result is taken as the actual solution because it includes the effects of shear deformation. In this work, the response obtained by experiment and that obtained by the finite strip method are assumed to be actual because they include the effects of shear deformation. The beam theory solution does not yield the actual response because it does not include the effects of shear deformation. Therefore, the deflection ratio is better defined as the ratio of the actual deflection to that of the beam theory solution.

\section{MATERIALS AND METHODS}

Several options exist for numerical solutions of thinwalled box girder bridges of which the most versatile is the finite element method. However, for bridges having regular geometric plans and simple boundary 
conditions, a full finite element analysis is often both extravagant and unnecessary

Halkude and Akim, [25]. The cost of solution can be high and usually jumps by an order of magnitude when a more refined higher dimensional analysis is required Cheung [26]. In such a case a finite strip analysis is found to be highly economical and less time consuming. Hence the numerical approach adopted in this work is the Finite Strip Method.

\subsection{Finite Strip Formulations for General Case of End Support Conditions}

From energy consideration of a plate strip and plane stress strip, the strain energy $U$ and the potential energy of external loading $\mathrm{W}$ give the following relations where the subscripts $b$ and $p$ denote bending and in-plane respectively:

$$
\begin{aligned}
& U_{b} \\
& =\frac{1}{2} \sum_{m=1}^{r} \sum_{n=1}^{r}\left\{\delta_{b}\right\}_{m}^{T} \int_{0}^{L} \int_{0}^{b}\left[B_{b}\right]_{m}^{T}\left[D_{b}\right]\left[B_{b}\right]_{n} d x d y\left\{\delta_{b}\right\}_{n} \\
& W_{b}=-\sum_{m=1}^{r}\left\{\delta_{b}\right\}_{m}^{T} \int_{0}^{L} \int_{0}^{b}\left[N_{b}\right]^{T} q(x, y) Y_{m}(y) d x d y
\end{aligned}
$$

Equations (1) and (2) can be expressed as equations

(1) and (2):

$$
\begin{gathered}
U_{b}=\frac{1}{2} \sum_{m=1}^{r} \sum_{n=1}^{r}\left\{\delta_{b}\right\}_{m}^{T}\left[k_{b}\right]_{m n}\{\delta\}_{n} \\
W_{b}=-\sum_{m=1}^{r}\left\{\delta_{b}\right\}_{m}^{T}\left\{p_{b}\right\}_{m}
\end{gathered}
$$

where,

$$
\begin{array}{r}
{[\mathrm{k}]_{\mathrm{mn}}=\left[\begin{array}{cccccccc}
k_{1 p} & k_{3 p} & 0 & 0 & k_{4 p} & k_{6 p} & 0 & 0 \\
k_{3 p} & k_{2 p} & 0 & 0 & -k_{6 p} & k_{5 p} & 0 & 0 \\
0 & 0 & k_{1 b} & k_{3 b} & 0 & 0 & k_{4 b} & -k_{5 b} \\
0 & 0 & k_{3 b} & k_{2 b} & 0 & 0 & k_{5 b} & k_{6 b} \\
k_{4 p} & -k_{6 p} & 0 & 0 & k_{1 p} & -k_{3 p} & 0 & 0 \\
k_{6 p} & k_{5 p} & 0 & 0 & -k_{3 p} & k_{2 p} & 0 & 0 \\
0 & 0 & k_{4 b} & k_{5 b} & 0 & 0 & k_{1 b} & -k_{3 b} \\
0 & 0 & -k_{5 b} & k_{6 b} & 0 & 0 & -k_{3 b} & k_{2 b}
\end{array}\right]} \\
\{\delta\}_{m}=\left[u_{i m} v_{i m} \omega_{i m} \theta_{i m} u_{j m} v_{j m} \omega_{j m} \theta_{j m}\right]^{T} \\
\{p\}_{m}=\left[X_{i m} Y_{i m} Z_{i m} M_{i m} X_{j m} Y_{j m} Z_{j m} M_{j m}\right]^{T}
\end{array}
$$

where,

The subscripts $\mathrm{p}$ and $\mathrm{b}$ in the stiffness matrix denote in-plane and bending terms respectively and the stiffness coefficients are given by:

$\mathrm{k}_{1 \mathrm{p}}=\mathrm{t}\left\{\left(\mathrm{C}_{1} / \mathrm{b}\right) \int_{0}^{L} Y_{m} Y_{n} d y+\left(\mathrm{C}_{4} \mathrm{~b} / 3\right) \int_{0}^{L} Y_{m}^{\prime} Y_{n}^{\prime} d y\right\} ; \ldots$ (16a)

$\mathrm{k}_{2 \mathrm{p}}=\mathrm{t}\left\{\left(\mathrm{C}_{2} / 2 \mu_{\mathrm{m}}\right) \int_{0}^{L} Y_{m}^{\prime \prime} Y_{n} d y+\left(\mathrm{C}_{4} / 2 \mu_{\mathrm{m}}\right) \int_{0}^{L} Y_{m}^{\prime} Y_{n}^{\prime} d y\right\} ; \ldots$ 


$$
\begin{aligned}
& \mathrm{k}_{3 \mathrm{p}}=\mathrm{t}\left\{\left(\mathrm{C}_{1} / \mathrm{b}\right) \int_{0}^{L} Y_{m} Y_{n} d y-\left(\mathrm{C}_{4} \mathrm{~b} / 6\right) \int_{0}^{L} Y_{m}^{\prime} Y_{n}^{\prime} d y\right\} ; \ldots \text { (16c) } \\
& \mathrm{k}_{4 \mathrm{p}}=\mathrm{t}\left\{\left(\mathrm{C}_{2} / 2 \mu_{\mathrm{m}}\right) \int_{0}^{L} Y_{m}^{\prime \prime} Y_{n} d y-\left(\mathrm{C}_{4} / 2 \mu_{\mathrm{m}}\right) \int_{0}^{L} Y_{m}^{\prime} Y_{n}^{\prime} d y\right\} ; \ldots \text { (16d) } \\
& \mathrm{k}_{5 \mathrm{p}}=\mathrm{t}\left\{\left(\mathrm{C}_{2} / 2 \mu_{\mathrm{n}}\right) \int_{0}^{L} Y_{m} Y_{n}^{\prime \prime} d y+\left(\mathrm{C}_{4} / 2 \mu_{\mathrm{n}}\right) \int_{0}^{L} Y_{m}^{\prime} Y_{n}^{\prime} d y\right\} ; \ldots \text { (16e) } \\
& \mathrm{k}_{6 \mathrm{p}}=\mathrm{t}\left\{\left(\mathrm{C}_{3} \mathrm{~b} / 3 \mu_{\mathrm{m}} \mu_{\mathrm{n}}\right) \int_{0}^{L} Y_{m}^{\prime \prime} Y_{n}^{\prime \prime} d y+\left(\mathrm{C}_{4} / \mathrm{b} \mu_{\mathrm{m}} \mu_{\mathrm{n}}\right) \int_{0}^{L} Y_{m}^{\prime} Y_{n}^{\prime} d y\right\} ; \ldots \text { (16f) } \\
& \mathrm{k}_{7 \mathrm{p}}=\mathrm{t}\left\{\left(\mathrm{C}_{2} / 2 \mu_{\mathrm{n}}\right) \int_{0}^{L} Y_{m} Y_{n}^{\prime \prime} d y-\left(\mathrm{C}_{4} / 2 \mu_{\mathrm{n}}\right) \int_{0}^{L} Y_{m}^{\prime} Y_{n}^{\prime} d y\right\} ; \ldots(16 \mathrm{~g}) \\
& \mathrm{k}_{8 \mathrm{p}}=\mathrm{t}\left\{\left(\mathrm{C}_{3} \mathrm{~b} / 6 \mu_{\mathrm{m}} \mu_{\mathrm{n}}\right) \int_{0}^{L} Y_{m}^{\prime \prime} Y_{n}^{\prime \prime} d y-\left(\mathrm{C}_{4} / \mathrm{b} \mu_{\mathrm{m}} \mu_{\mathrm{n}}\right) \int_{0}^{L} Y_{m}^{\prime} Y_{n}^{\prime} d y\right\} ; \ldots \text { (16h) } \\
& \mathrm{k}_{1 \mathrm{~b}}=\left(5040 \mathrm{D}_{\mathrm{x}} \int_{0}^{L} Y_{m} Y_{n} d y-504 \mathrm{D}_{1} \mathrm{~b}^{2} \int_{0}^{L} Y_{m}^{\prime \prime} Y_{n} d y-504 \mathrm{D}_{1} \mathrm{~b}^{2} \int_{0}^{L} Y_{m} Y_{n}^{\prime \prime} d y+\right. \\
& \left.156 \mathrm{D}_{\mathrm{y}} \mathrm{b}^{4} \int_{0}^{L} Y_{m}^{\prime \prime} Y_{n}^{\prime \prime} d y+2016 \mathrm{D}_{\mathrm{xy}} \mathrm{b}^{2} \int_{0}^{L} Y_{m}^{\prime} Y_{n}^{\prime} d y\right) / 420 \mathrm{~b}^{3} ; \\
& \mathrm{k}_{2 \mathrm{~b}}=\left(1680 \mathrm{D}_{\mathrm{x}} \mathrm{b}^{2} \int_{0}^{L} Y_{m} Y_{n} d y-56 \mathrm{D}_{1} \mathrm{~b}^{4} \int_{0}^{L} Y_{m}^{\prime \prime} Y_{n} d y-56 \mathrm{D}_{1} \mathrm{~b}^{4} \int_{0}^{L} Y_{m} Y_{n}^{\prime \prime} d y+\right. \\
& \left.4 \mathrm{D}_{\mathrm{y}} \mathrm{b}^{6} \int_{0}^{L} Y_{m}^{\prime \prime} Y_{n}^{\prime \prime} d y+224 \mathrm{D}_{\mathrm{xy}} \mathrm{b}^{4} \int_{0}^{L} Y_{m}^{\prime} Y_{n}^{\prime} d y\right) / 420 \mathrm{~b}^{3} ; \ldots \text { (17b) } \\
& \mathrm{k}_{3 \mathrm{~b}}=\left(2520 \mathrm{D}_{\mathrm{x}} \mathrm{b} \int_{0}^{L} Y_{m} Y_{n} d y-462 \mathrm{D}_{1} \mathrm{~b}^{3} \int_{0}^{L} Y_{m}^{\prime \prime} Y_{n} d y-42 \mathrm{D}_{1} \mathrm{~b}^{3} \int_{0}^{L} Y_{m} Y_{n}^{\prime \prime} d y+\right. \\
& \left.22 \mathrm{D}_{\mathrm{y}} \mathrm{b}^{5} \int_{0}^{L} Y_{m}^{\prime \prime} Y_{n}^{\prime \prime} d y+168 \mathrm{D}_{\mathrm{xy}} \mathrm{b}^{3} \int_{0}^{L} Y_{m}^{\prime} Y_{n}^{\prime} d y\right) / 420 \mathrm{~b}^{3} ; \ldots \text { (17c) } \\
& \mathrm{k}_{4 \mathrm{~b}}=\left(-5040 \mathrm{D}_{\mathrm{x}} \int_{0}^{L} Y_{m} Y_{n} d y+504 \mathrm{D}_{1} \mathrm{~b}^{2} \int_{0}^{L} Y_{m}^{\prime \prime} Y_{n} d y+504 \mathrm{D}_{1} \mathrm{~b}^{2} \int_{0}^{L} Y_{m} Y_{n}^{\prime \prime} d y+\right. \\
& \left.54 \mathrm{D}_{\mathrm{y}} \mathrm{b}^{4} \int_{0}^{L} Y_{m}^{\prime \prime} Y_{n}^{\prime \prime} d y-2016 \mathrm{D}_{\mathrm{xy}} \mathrm{b}^{2} \int_{0}^{L} Y_{m}^{\prime} Y_{n}^{\prime} d y\right) / 420 \mathrm{~b}^{3} ; \ldots \text { (17d) } \\
& \mathrm{k}_{5 \mathrm{~b}}=\left(-2520 \mathrm{D}_{\mathrm{x}} \mathrm{b} \int_{0}^{L} Y_{m} Y_{n} d y+42 \mathrm{D}_{1} \mathrm{~b}^{3} \int_{0}^{L} Y_{m}^{\prime \prime} Y_{n} d y+42 \mathrm{D}_{1} \mathrm{~b}^{3} \int_{0}^{L} Y_{m} Y_{n}^{\prime \prime} d y+\right. \\
& \left.13 \mathrm{D}_{\mathrm{y}} \mathrm{b}^{5} \int_{0}^{L} Y_{m}^{\prime \prime} Y_{n}^{\prime \prime} d y-168 \mathrm{D}_{\mathrm{xy}} \mathrm{b}^{3} \int_{0}^{L} Y_{m}^{\prime} Y_{n}^{\prime} d y\right) / 420 \mathrm{~b}^{3} ; \ldots \text { (17e) } \\
& \mathrm{k}_{6 \mathrm{~b}}=\left(840 \mathrm{D}_{\mathrm{x}} \mathrm{b}^{2} \int_{0}^{L} Y_{m} Y_{n} d y+14 \mathrm{D}_{1} \mathrm{~b}^{4} \int_{0}^{L} Y_{m}^{\prime \prime} Y_{n} d y+14 \mathrm{D}_{1} \mathrm{~b}^{4} \int_{0}^{L} Y_{m} Y_{n}^{\prime \prime} d y-\right. \\
& \left.3 \mathrm{D}_{\mathrm{y}} \mathrm{b}^{6} \int_{0}^{L} Y_{m}^{\prime \prime} Y_{n}^{\prime \prime} d y-56 \mathrm{D}_{\mathrm{xy}} \mathrm{b}^{4} \int_{0}^{L} Y_{m}^{\prime} Y_{n}^{\prime} d y\right) / 420 \mathrm{~b}^{3} \text {; }
\end{aligned}
$$

where,

$\mathrm{L}$ is the length of strip; $\mathrm{b}$ is the width of strip; $\mathrm{t}$ is the thickness of strip; $\mathrm{E}$ is the elastic modulus; $\mathrm{G}_{\mathrm{xy}}$ is the shear modulus and $\mathrm{v}$ is the Poisson's ratio

Note that $u_{m}, u_{n}$ are obtained from the solution of the beam vibration differential equation and $Y_{m}, Y_{n}$ are functions of $\mu_{m}, \mu_{n}$ respectively.

It can be seen that the stiffness matrix for the flat shell strip contains five types of integrals, namely:

$I N T_{1}=\int_{0}^{L} Y_{m} Y_{n} d y ; I N T_{2}=\int_{0}^{L} Y_{m}^{\prime \prime} Y_{n} d y ; I N T_{3}=\int_{0}^{L} Y_{m} Y_{n}^{\prime \prime} d y ; I N T_{4}=\int_{0}^{L} Y_{m}^{\prime \prime} Y_{n}^{\prime \prime} d y ;$

$I N T_{5}=\int_{0}^{L} Y_{m}^{\prime} Y_{n}^{\prime} d y$

It can be proved that the beam eigenfunctions possess the valuable properties of orthogonality i.e.

$$
\begin{array}{ll}
\int_{0}^{L} Y_{m} Y_{n} d y=0 & \text { for } m \neq n \\
\int_{0}^{L} Y_{m}^{\prime \prime} Y_{n}^{\prime \prime} d y=0 & \text { for } m \neq n
\end{array}
$$

However the integrals $I N T_{2}, I N T_{3}$, and $I N T_{5}$ will not in general varnish for $m \neq n$.Consequently, the different series terms are coupled, i.e. $[\mathrm{K}]_{\mathrm{mn}} \neq 0$ for $m \neq n$,unless the strip is simply supported.

\subsubsection{Equilibrium Equation}

The equilibrium equation takes the form

$$
[\mathrm{K}]_{\mathrm{tmn}}\{\delta\}_{t m}=\{F\}_{t m} \ldots(21 \mathrm{a})
$$




$$
\left[\begin{array}{cccccc}
{[\mathrm{k}]_{\mathrm{t} 11}} & {[\mathrm{k}]_{\mathrm{t} 11}} & \cdot & \cdot & \cdot & {[\mathrm{k}]_{\mathrm{t} 1 \mathrm{r}}} \\
{[\mathrm{k}]_{\mathrm{t} 21}} & {[\mathrm{k}]_{\mathrm{t} 21}} & \cdot & \cdot & \cdot & {[\mathrm{K}]_{\mathrm{t} 2 \mathrm{r}}} \\
\cdot & \cdot & \cdot & \cdot & \cdot & \cdot \\
\cdot & \cdot & \cdot & \cdot & \cdot & \cdot \\
\cdot & \cdot & \cdot & \cdot & \cdot & \cdot \\
{[\mathrm{K}]_{\mathrm{tr} 1}} & {[\mathrm{~K}]_{\mathrm{tr} 2}} & \cdot & \cdot & \cdot & {[\mathrm{K}]_{\mathrm{trr}}}
\end{array}\right]\left\{\begin{array}{c}
\{\delta\}_{t 1} \\
\{\delta\}_{t 2} \\
\cdot \\
\cdot \\
\cdot \\
\{\delta\}_{t r}
\end{array}\right\}=\left\{\begin{array}{c}
\{P\}_{t 1} \\
\{P\}_{t 2} \\
\cdot \\
\cdot \\
\cdot \\
\{P\}_{t r}
\end{array}\right\}
$$

$[\mathrm{k}]_{\mathrm{tmn}}$ is a $4 \mathrm{~N} \mathrm{X} 4 \mathrm{~N}$ matrix given by

$[\mathrm{k}]_{\mathrm{tmn}}=\sum_{\mathrm{i}=0}^{\mathrm{S}}[\mathrm{k}]_{\mathrm{mn}} \ldots(22)$

where,

$$
\begin{aligned}
& N=\text { Number of nodal lines } \\
& S=\text { Number of finite strips }
\end{aligned}
$$

$[\mathrm{K}]_{\mathrm{tmn}}$ is a $4 \mathrm{Nr} \mathrm{X} 4 \mathrm{Nr}$ matrix

\subsection{Experimental Modeling}

Two-point loading system is applied to six prototype simply supported reinforced concrete box girder bridge models, made in the scale1:10 with respect to typical prototype box Girder Bridge. The specimens are made of the same length. However, with regards to the flange width, the specimens are grouped into three types of two models each. So the prototype model Type I had the widest flange width while prototype model Type III had the least flange width. The dimensions of the specimen are chosen in conformity to the thin-walled cross-section theory. The set-up, specimen and instrumentation are defined. Seven different load cases are applied to each specimen. The load/deformation relationship is obtained and plotted in graphs together with the finite strip analysis results of the same loading condition. The load/deformation relationship is presented in the form of deflection ratios in which the beam theory solution is taken as the bench mark. Useful inferences are made from the results of analyses and the graphs.

\subsubsection{The Prototype Box Girder Bridge Models}

Six Prototype Box Girder Bridge models (the specimens), made of reinforced concrete, are used for the experiment. The weight of the specimens, together with the thin-walled cross-section theory, was considered in choosing the specimen dimensions. $800 \mathrm{Kg}$ is the weight carrying capacity of the movable crane which is used for carrying and placing the specimen for experiments and, therefore, an upper limit of $700 \mathrm{~kg}$ is chosen for the weight of each specimen. So the thickness of the walls of the crosssection has to be as small as is practically possible with a minimum matching length. The thickness of the web and flanges was selected as $46 \mathrm{~mm}$ by considering the smallest possible thickness to accommodate $15 \mathrm{~mm}$ cover on both faces of wall with single reinforcement mat using $8 \mathrm{~mm}$ diameter high tensile reinforcement bars in both transverse and longitudinal directions. The total length of each specimen is $3220 \mathrm{~mm}$ with a simply supported span of $3000 \mathrm{~mm}$.

The chosen dimensions of the specimen conform to the thin-walled cross-section theory and represent a scale of $1 / 10$ in relation to the prototype bridges usually encountered in practice. The complete dimensions of the Six Prototype Box Girder Bridge models are shown in Table 1 and Figures $1-3$.

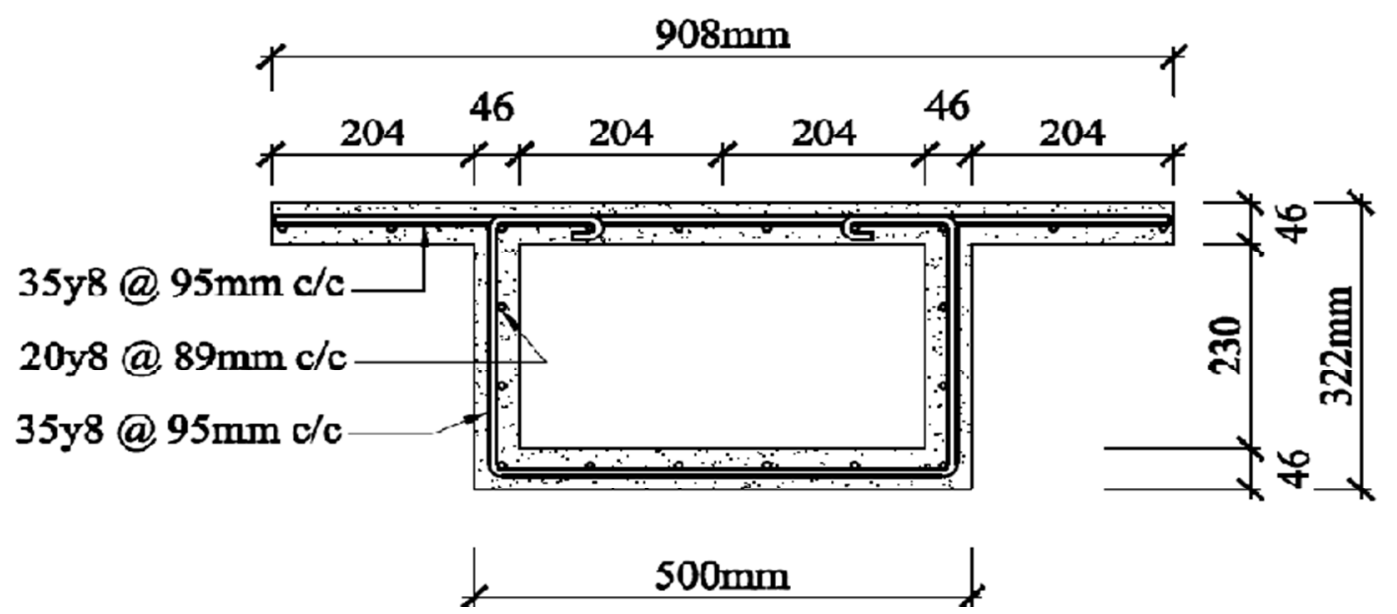

Figure 1 Cross-Section of Type I Box Girder Bridge Model 


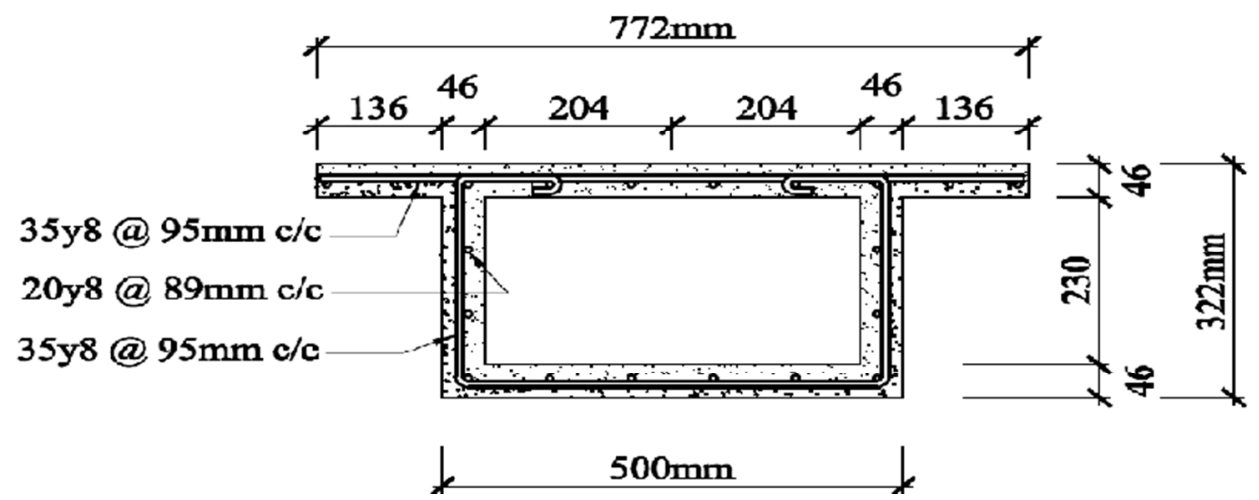

Figure 2 Cross-Section of Type II Box Girder Bridge Model

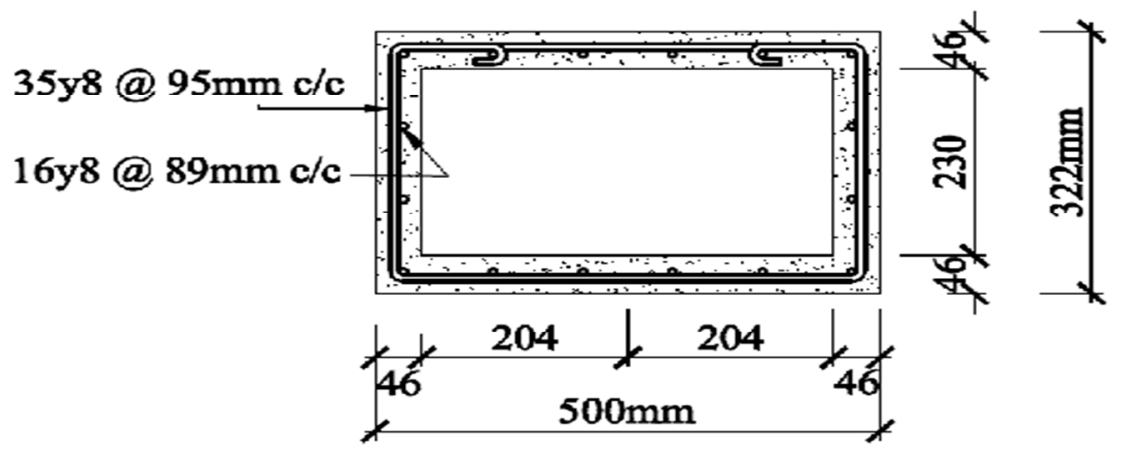

Figure 3 Cross-Section of Type III Box Girder Bridge Model

Table 1: Specimen Dimensions (m)

\begin{tabular}{ccccccccc}
\hline \multicolumn{7}{c}{ Overall Length $=3.22$, Span $=3.00$} \\
\hline \multirow{2}{*}{$\begin{array}{c}\text { Prototype } \\
\text { Model }\end{array}$} & Quantity & \multicolumn{7}{c}{ Top Flange } \\
\cline { 2 - 9 } & Width & $\begin{array}{c}\text { Cantilever } \\
\text { Arm }\end{array}$ & Thickness & Width & Thickness & $\begin{array}{c}\text { Overall } \\
\text { Depth }\end{array}$ & Thickness \\
\hline Type I & 2 & 0.500 & 0.204 & 0.046 & 0.500 & 0.046 & 0.322 & 0.046 \\
\hline Type II & 2 & 0.500 & 0.136 & 0.046 & 0.500 & 0.046 & 0.322 & 0.046 \\
\hline Type III & 2 & 0.500 & 0.00 & 0.046 & 0.500 & 0.046 & 0.322 & 0.046 \\
\hline
\end{tabular}

Portland Pozzolana Cement, fine aggregate, and $10 \mathrm{~mm}$ coarse aggregate conforming to Indian Standards (BIS, 2000) were used. The cement, fine aggregate, coarse aggregate, and water were mixed in the proportions of 1:1.76:3.18:0.4, based on preliminary trial mixes, and arrived at M35 grade concrete. The results of the control specimen tests are given in Table......

High tensile rods, $8 \mathrm{~mm}$ diameter, were used for the preparation of the reinforcement cage in both the longitudinal and transverse directions (see Figs. 1 - 3) with $15 \mathrm{~mm}$ concrete cover on both faces.

Young's Modulus are obtained from the following formula using Indian Standards.

$\mathrm{E}_{\mathrm{c}}=5000 \sqrt{\mathrm{f}_{\mathrm{ck}}}$

Where $E_{c}$ is the short term static modulus of elasticity in $\mathrm{N} / \mathrm{mm}^{2}$ (or $\mathrm{MPa}$ )

$\mathrm{f}_{\mathrm{ck}}=35 \mathrm{~N} / \mathrm{mm}^{2}$, for M35

$\therefore \mathrm{E}_{\mathrm{c}}=29,580 \mathrm{~N} / \mathrm{mm}^{2}$ $\therefore$ Use $\mathrm{E}_{\mathrm{c}}=30 \times 10^{6} \mathrm{KPa}$, or $\mathrm{E}_{\mathrm{c}}=30,000 \mathrm{MPa}$

Table 2: Strength of Concrete $\left(\mathrm{N} / \mathrm{mm}^{2}\right)$--- Control Specimen Tests

\begin{tabular}{ccc}
\hline S/No & $\begin{array}{r}\text { 28 Days Cube } \\
\text { Strength }\end{array}$ & $\begin{array}{c}\text { Characteristic } \\
\text { Comp. Strength }\end{array}$ \\
\hline 1 & 43.55 & 35.30 \\
2 & 43.05 & 34.80 \\
3 & 44.15 & 35.90 \\
4 & 43.75 & 35.50 \\
5 & 43.60 & 35.35 \\
6 & 43.45 & 35.20 \\
\hline
\end{tabular}

The form work is constructed with $12 \mathrm{~mm}$ thick impermeable plywood. Triangular wooden frames are used as temporary bracings and supports for the form work at the flanges and box section to improve stability of cross-sections; minimize cross-sectional 
distortions; and eliminate deflection of the flanges during casting when no composite action is available between the concrete and reinforcement. In addition the formwork in the box section is made into two detachable parts for ease of removal during dismantling operations. The instrumentation and experimental setup was conducted at BITS Pilani, India.

Two-point loading system was applied. A point load is applied to a distributing beam which creates a system of two point loads. The distributing beam is supported on two steel half-cylinders which actually stimulates the two loading points on the test specimen (see Figure 4). The hydraulic jock, which is connected to the loading frame, is used to generate the applied loads (concentrated loads). Preloading was first executed, before formal loading process, to confirm that the specimens were in expected status and assure reliability of all test equipments. Data related to preloading are not listed because of specimen initial imperfection.

The deflection of the prototype box girder bridge was measured by a displacement transducers (LVDT) located underneath the center of the bottom flange. The load cells act as simple supports to the specimen.
Reactions at the support are measured by the load cells. All measuring devices or cells are connected to the Data Acquisition System.

3.3 The Finite Strip Models of the prototype box girders Figure 5 shows the longitudinal section of a typically loaded prototype box girder bridge while Figures 6 to 8 shows the finite strip models used in the theoretical analysis of the prototype box girders. The developed software programme is used for the theoretical analysis.

\section{ANALYSIS AND RESULTS}

Results of the analysis are presented in Figures $9-14$. The beam theory solution is used as the benchmark in the experimental study and so it had a deflection ratio of 1.00 for all loading cases. In prototype model Type I, made up of specimens 1 and 2, the mean value of the experimental deflection ratios was 1.23 for each specimen while that of the computer program was1.22. In prototype model Type II, made up of specimens 3 and 4 , the mean value of the experimental deflection ratios was 1.22 for each specimen while that of the computer program was 1.21 .

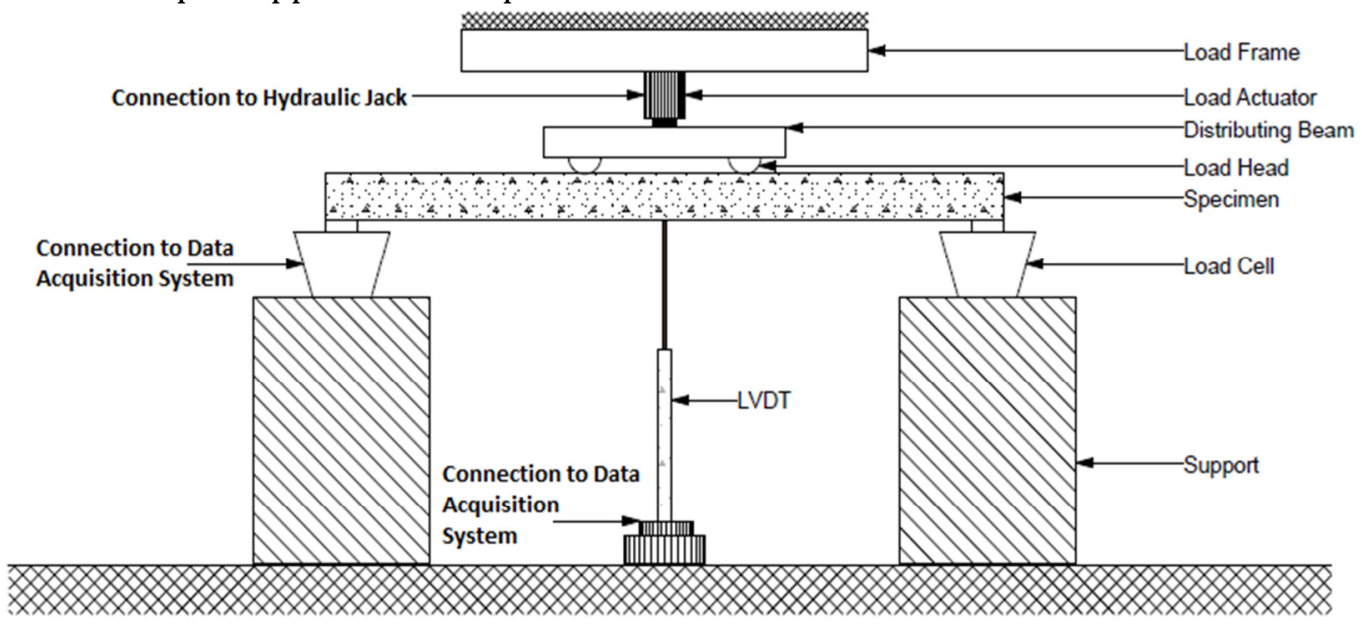

Figure 4 Schematic diagram of experimental setup

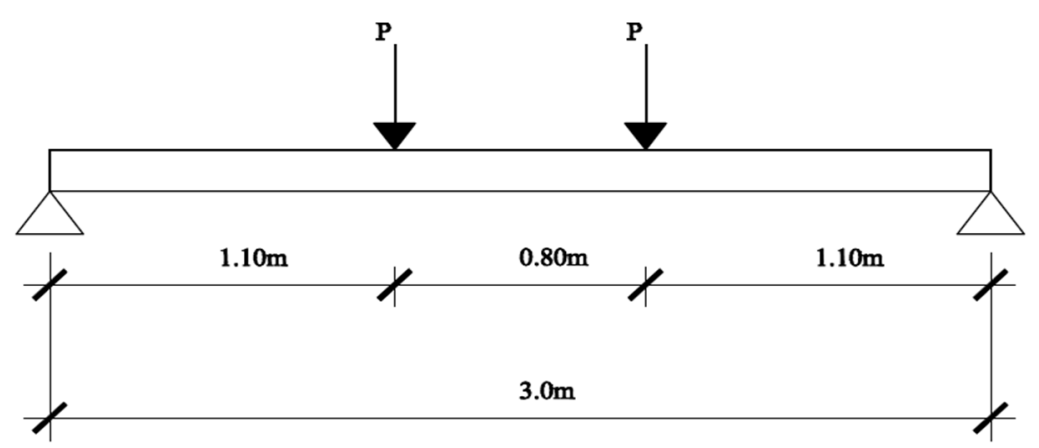

Figure 5: Longitudinal section of typical prototype box girder bridge model 
In prototype model Type III, made up of specimens 5 and 6 , the mean value of the experimental deflection ratios was 1.18 for each specimen while that of the computer program was 1.17. From the results, the mean values of the deflection ratio obtained by experiment were higher than that of the program by values less than $2 \%$. Prototype Model Type I recorded the highest deflection ratio.

\subsection{Numerical Analysis}

A simply supported concrete box girder bridge with span $\mathrm{L}=40 \mathrm{~m}$ is subjected to self-weight and eight point forces, which are symmetrical about the midspan and centerline of cross-section and have magnitude $\mathrm{P}=50 \mathrm{kN}$ each, as shown in Figs. 15 and 16. The cross-section has a top flange of thickness 0.3 $\mathrm{m}$, a bottom flange of thickness $0.5 \mathrm{~m}$ and two webs of thickness $0.4 \mathrm{~m}$. The material properties are $\mathrm{E}=30000 \mathrm{Mpa}$ and $v=0.15$.The specific gravity is $\gamma=24 \mathrm{kNm}^{-3}$.

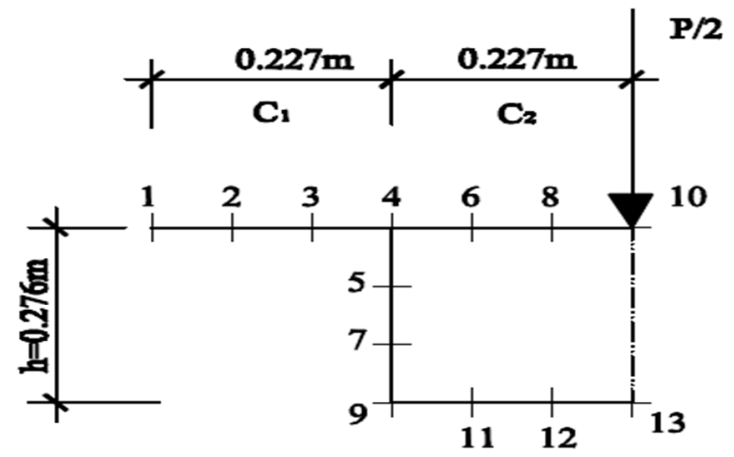

Figure 6 Finite strip model for type i (12 strips) showing nodal lines for symmetrical half of the bridge

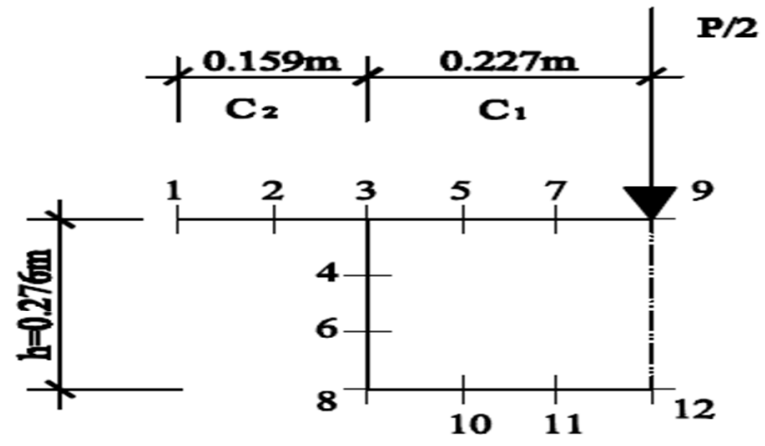

Figure 7 Finite strip model for type ii (11 strips) showing nodal lines for symmetrical half of the bridge

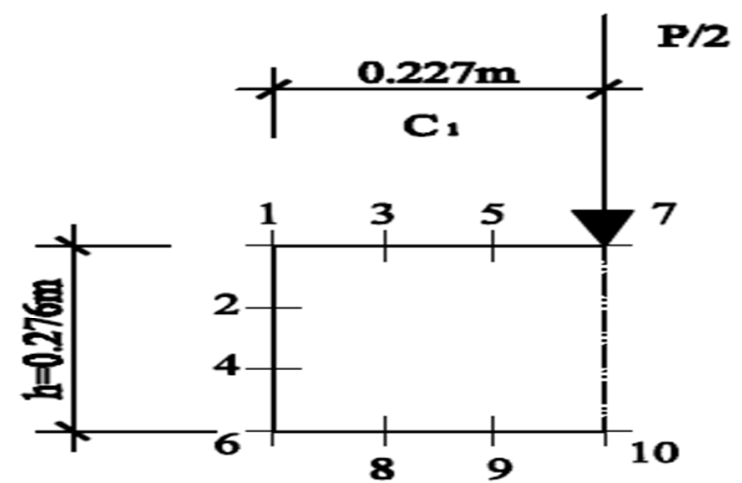

Figure 8 Finite strip model for type iii (9 strips) showing nodal lines for symmetrical half of the bridge

The results obtained by using the software program in MATLAB are exactly the same with that of Cheung et al. (1996) for the deflections (Figure 18) and moments (Figure 20). However, minor differences exist in the longitudinal normal stresses (Figure 19) in which case the results in parentheses are that of Cheung et al. (1996).

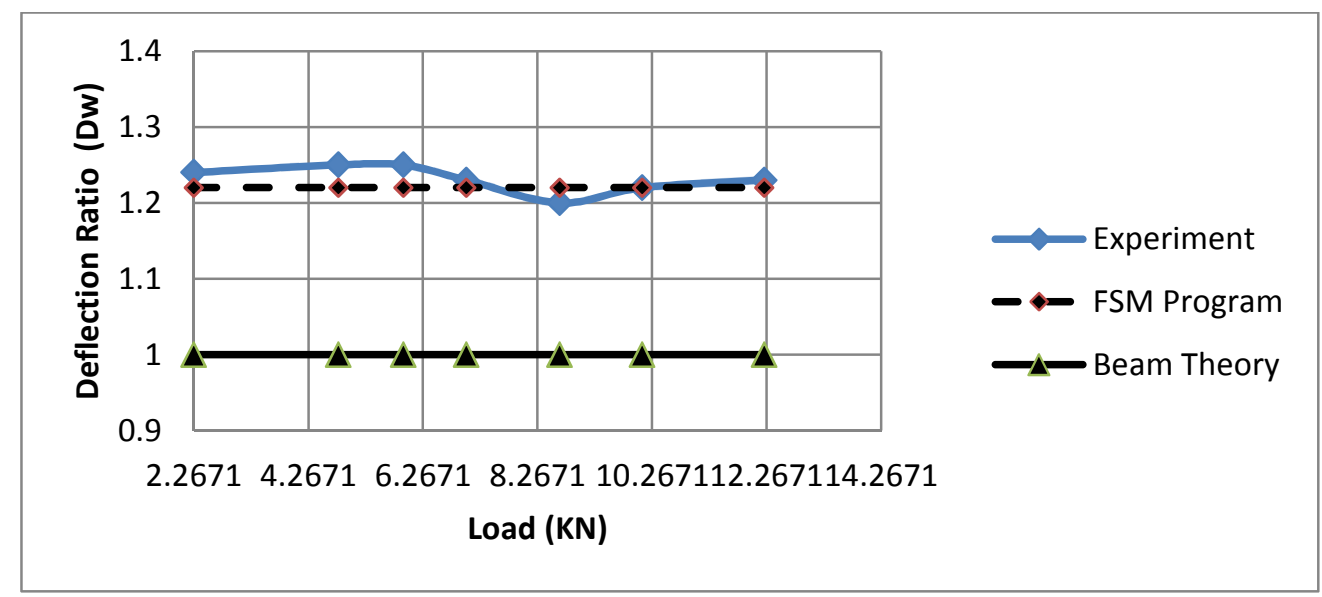

Figure 9 Deflection Ratios for Specimen 1 (Prototype Model I) 


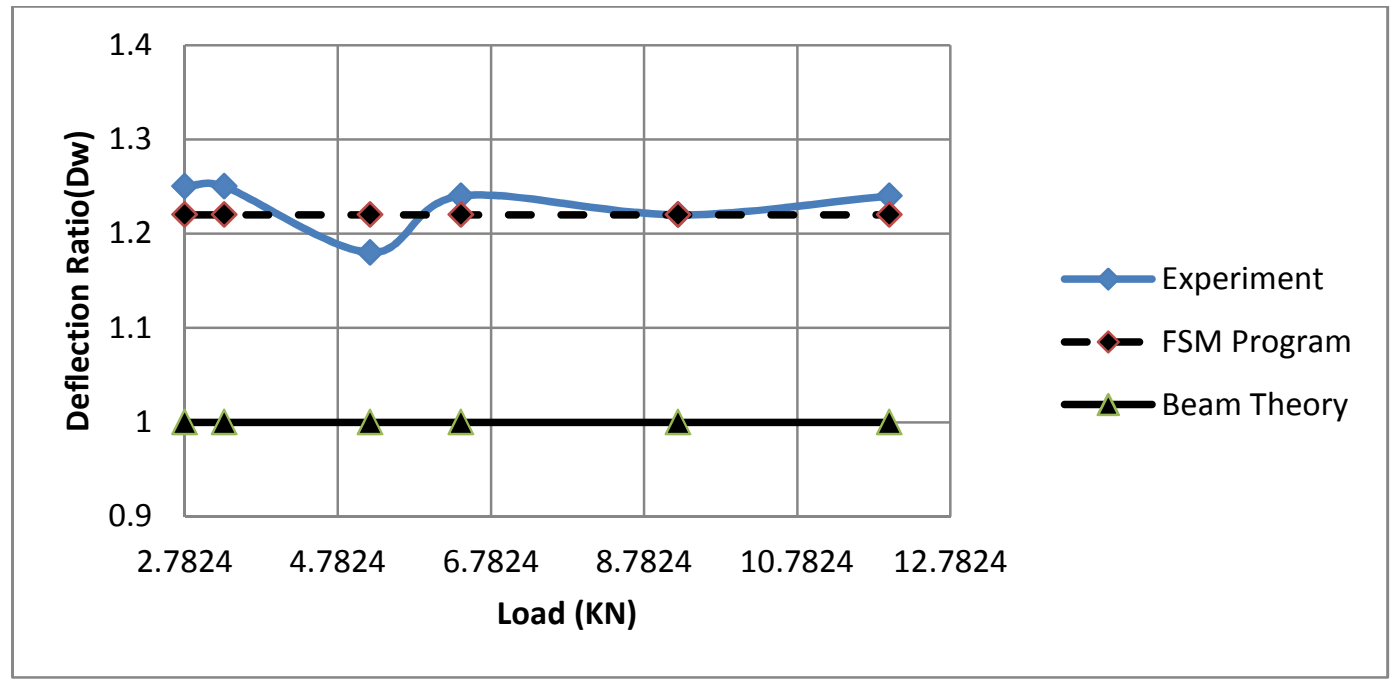

Figure 10: Deflection Ratios for Specimen 2 (Prototype Model I)

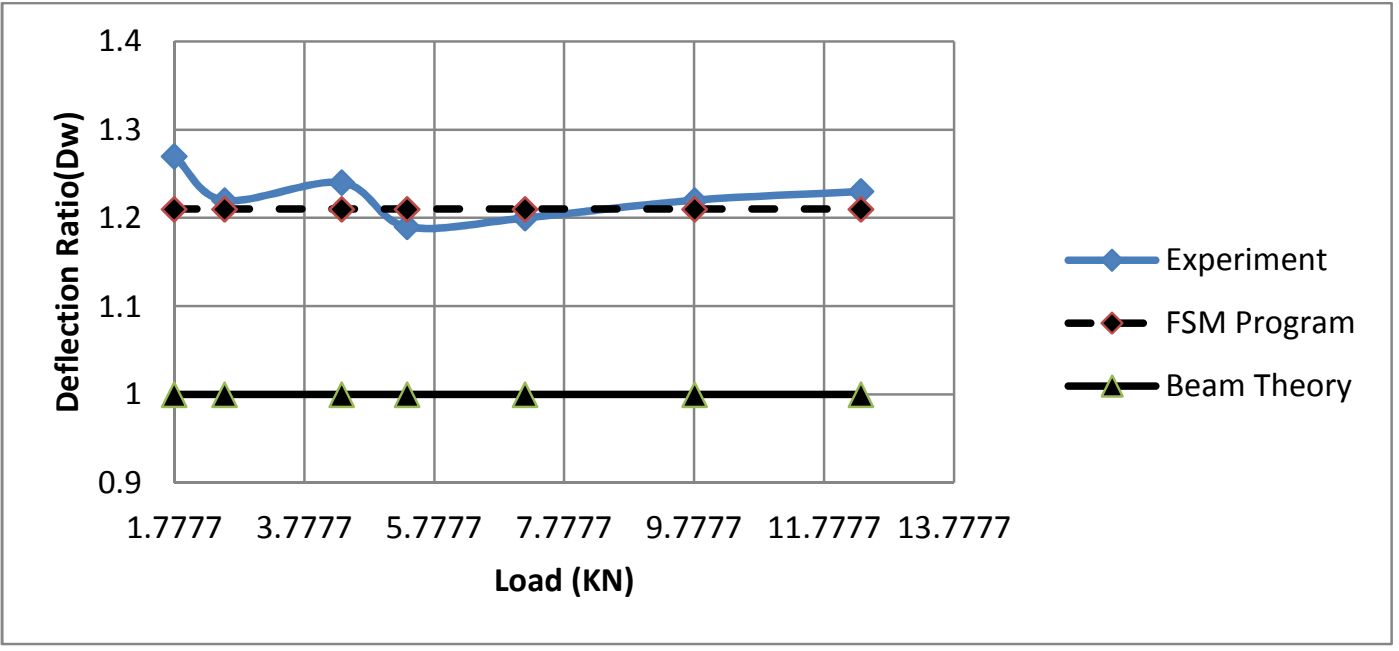

Figure 11: Deflection Ratios for Specimen 3 (Prototype Model II)

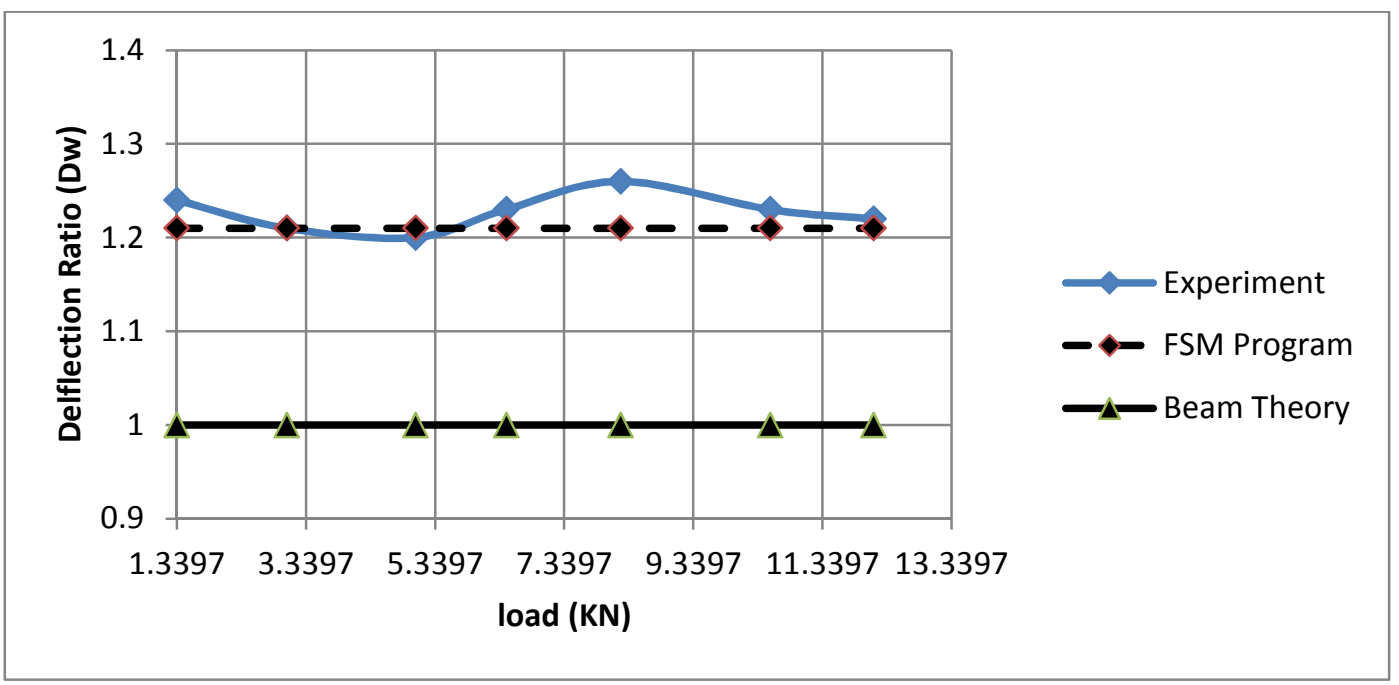

Figure 12: Deflection Ratios for Specimen 4 (Prototype Model II) 


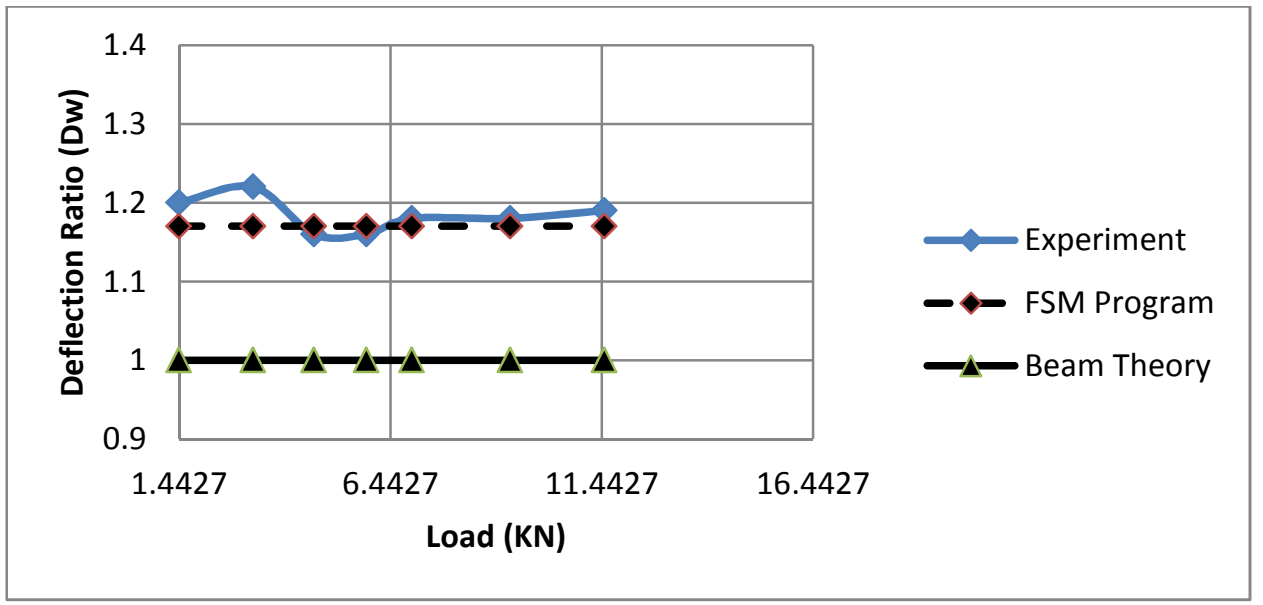

Figure 13: Deflection Ratios for Specimen 5 (Prototype Model III)

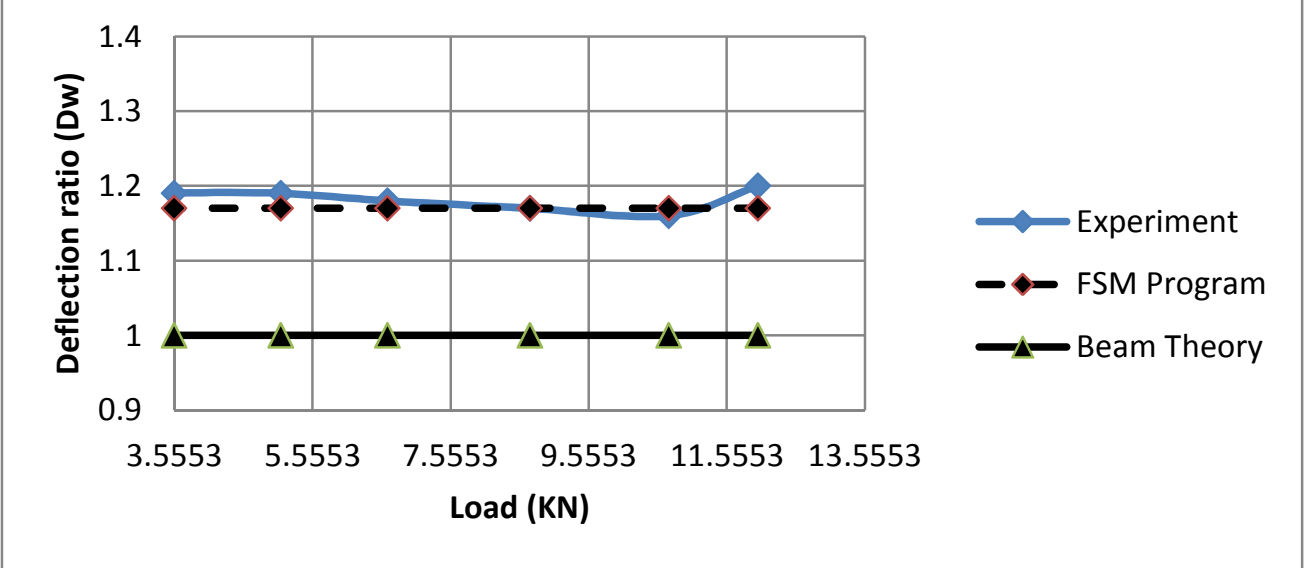

Figure 14: Deflection Ratios for Specimen 6 (Prototype Model III)

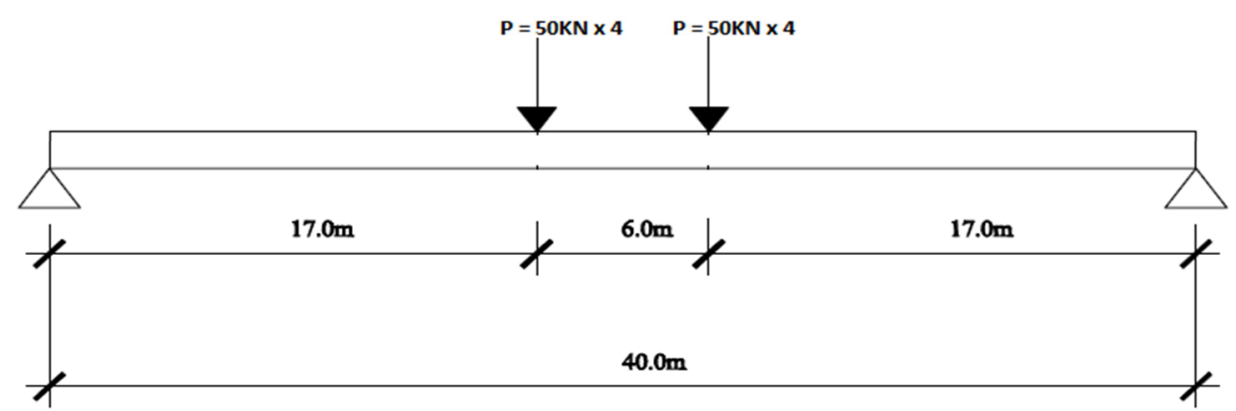

Figure15 Longitudinal section of simply supported box Girder Bridge

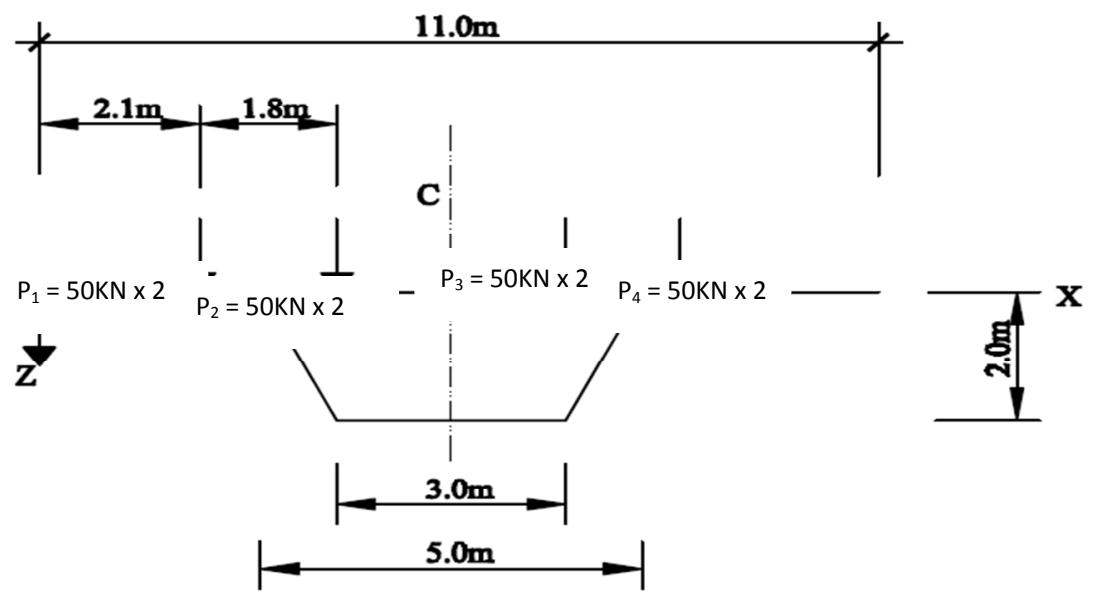

Figure 16 Cross section of simply supported box Girder Bridge 
Table 3 Comparison with Beam Theory Solution

\begin{tabular}{llll}
\hline $\begin{array}{l}\text { Analytical } \\
\text { Method }\end{array}$ & $\begin{array}{l}\text { Maximum } \\
\text { Deflection } \\
(\mathrm{m})\end{array}$ & $\begin{array}{l}\text { Maximum Longitudinal } \\
\text { Normal Stress in Flange } \\
(\mathrm{MPa})\end{array}$ \\
\cline { 3 - 4 } & & Top & Bottom \\
\hline $\begin{array}{l}\text { Beam Theory } \\
\text { Cheung et. al.[7] }\end{array}$ & 0.0389 & -6.19 & 10.76 \\
$\begin{array}{l}\text { Proposed } \\
\text { FSMProgramme }\end{array}$ & 0.0414 & -5.25 & 8.99 \\
\hline
\end{tabular}

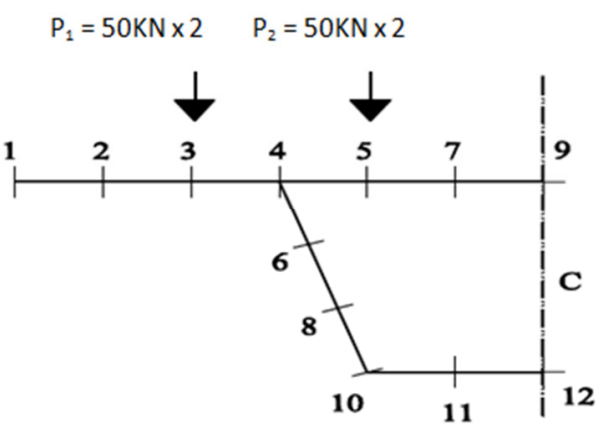

Figure 17: The finite strip model (11 Strips) showing Nodal Lines for symmetrical half of the bridge

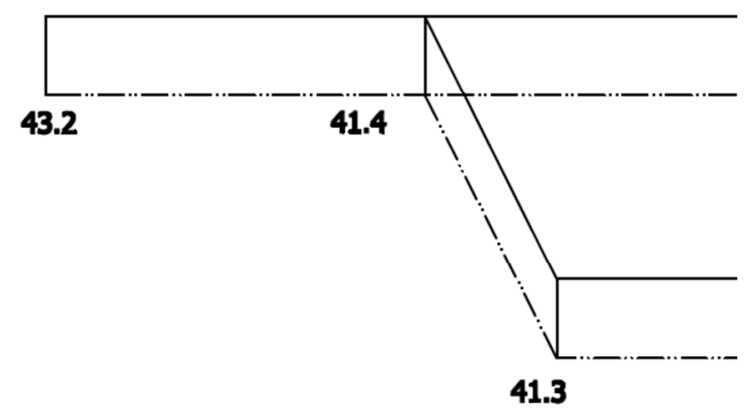

Figure 18 Deflection (mm)

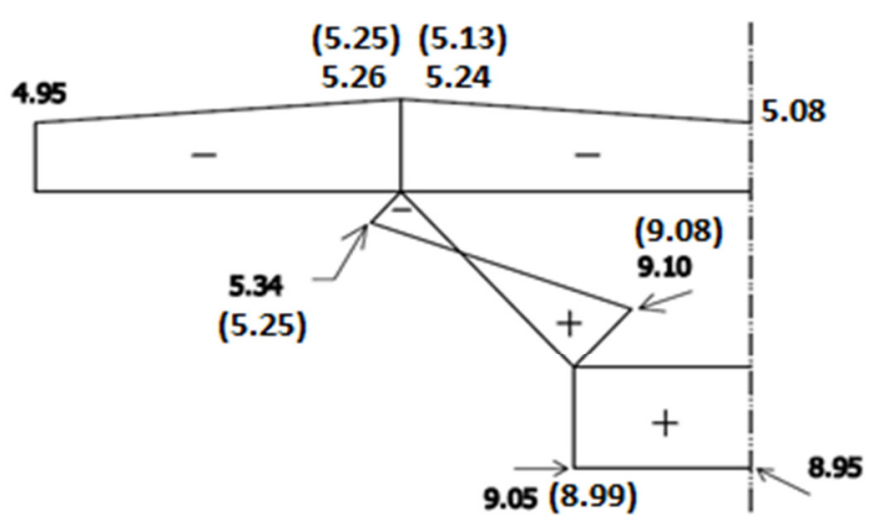

Figure 19 Longitudinal normal stress (MPa)

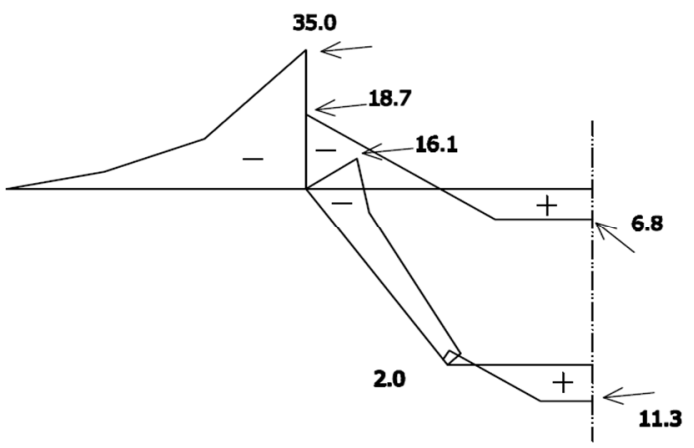

Figure 20 Transverse bending moment $(\mathrm{kNm} / \mathrm{m})$

\subsection{DISCUSSION OF RESULTS}

The plots in Figure 9 to Figure 14 show that the finite strip solution of the static response of the six prototype models and that of experiment show close agreement. Both solutions do not show any close agreement with the beam theory solution. Also, the finite strip solution portray a perfectly linearly elastic response as shown in the straight line graphs where as the plotted experimental results show similar trends which are not necessarily straight line graphs. The close agreement in result between the finite strip solution and that of the experiment can be attributed to the fact that both cases include the effects of shear deformation. The result of the beam theory solution is much lower than that of the finite strip and experiment. This can be attributed to the fact that the beam theory solution does not include the effects of shear deformation.

The theoretical analysis results presented in Figure 18 to 20 shows that the results obtained by developed software program are in very good agreement with that of literature presented by Cheung et al. [7]. Table 3 shows the comparism of the maximum deflections and longitudinal normal stresses in Figure 18 and Figure 20 respectively, with that obtained by the beam theory solution. These results show that the finite strip solution obtained by the developed software and that obtained by Cheung et al. [7] show very good agreement and both differ greatly from the beam theory solution. These results validate the developed software programme.

\section{CONCLUSION}

Experimental studies and finite strip analysis of thinwalled box girder bridges have been conducted and presented herein. A software produced in MATLAB developed by Ezeokpube [6] is used for the finite strip analysis. Response results obtained in the computer program and model experiment show 
excellent agreement and are, averagely, $19.5 \%$ and $21.5 \%$ higher than that of the beam theory solution respectively. The use of bridge measuring instruments was employed in the experimental studies. Apart from being used to validate the software program, the experimental studies further increased the understanding of the physical behavior of thin-walled box girder bridges under service load by showing that the effects of shear deformation increases with increase in the flange width of thinwalled box girder bridges. So the greatest response occurred in the prototype box girder bridge Type I which has the widest flange while the least response occurred in Type III which has the smallest flange. This is a very important phenomenon in the behavior of thin-walled box girder bridges showing that the effect of shear deformation is highly pronounced in wide flanged box girder bridges.

Furthermore, the prototype models had a distinct deflection ratio which is fairly constant irrespective of the loading. It can, therefore, be inferred that the mechanical and geometric properties of each set of the prototype models is consistent. This validates the construction methods and assumptions used for preparing the prototype models.

Based on the study, the following suggestions are made: (1) though the program was formulated with flat shell strips for continuous structures, it applies in practice for use in the analysis of both continuous and simply supported thin-walled box girder bridges, box beams, and prismatic folded plate structures; (2) the model experiment and numerical evaluation indicated that the effect of shear deformation increases with increases in flange width; and (3) by comparison with the beam theory formulations it can be seen that the effect of shear deformation is greater on deflection than on stresses.

\section{REFERENCES}

1. Sennah, K. M. and Kennedy, J. B. (2002), Literature Review in Analysis of Box Girder Bridges, J. of Bridge Engineering, 7 (2), pp. 134-143.

2. Kulicki, J. M., Wassef, W. G., Kleinhans, D. D., Yoo, C. H. Nowak, A. S., and Grubb, M. (2006), Development of LRFD Specifications for Horizontally Curved Steel Girder Bridges, National Cooperative Highway Research Program (NCHRP), NCHRP report 563, Washington.

3. Huang, D. Z. (2004), Field Test and Rating of Arlington Curved Steel Box Girder Bridge, Transportation and Research Record. 1892,
Transportation and Research Board, Washington D.C.

4. Huang, D. Z. (2008), Full-Scale Test and Analysis of a Curved Steel-Box Girder Bridge, J. of Bridge Engineering, 13(5), pp. 492-500.

5. Huang, D. Z., Ansley, M., Roufa, G. (2004), "Bridge testing report Veteran's Memorial Bridge ", Rep. No. SRC-H001-04, Florida Department of transportation, Structures Research Center, Tallahassee, Fla.

6. Ezeokpube, G. C. (2013). Finite Strip Analysis of Continuous Thin-Walled Box girder Bridges, $\mathrm{PhD}$ Thesis, University of Nigeria Nsukka (UNN).

7. Cheung, M. S., Li, W. and Chidiac, S. E. (1996), Finite Strip Analysis of Bridges, $1^{\text {st }}$ Ed., E \& FN SPON, London.

8. Nakai, H., Miki, T., and Sumiyoshika, S. (1980). Theoretical and Experimental Research on Distortion of Thin-Walled Horizontally Curved Box Girder Bridges. J. Civ. Eng., 2(1), pp. 63-101.

9. Shanmugam, N. E., and Balendra, T. (1985). Model Studies of Multi-Cell Structures. Proc. Inst. Civ. Eng., London. 79(2), pp. 55-71.

10. Shanmugam, N. E., and Balendra, T. (1991). Experimental and Theoretical Study of Multi-Cell Structures Curved in Plan. Thin-Walled Struct, 12(5), 373-387.

11. Luo, Q. Z., Wu, Y. W., Tang, J, and Li, Q. S. (2002), Experimental Studies on Shear Lag of Box Girders, Engineering Structures, Vol. 24, pp. 469-477

12. Luo, Q. Z., Wu, Y. W., Li, Q. S., Tang, J., and Liu, G. D. (2004), A Finite Segment Model for Shear Lag Analysis, Engineering Structures, , Vol. 26, pp. 21132124.

13. Zhang, H., DesRoches, R., Yang, Z., and Liu, S. (2010), Experimental and Analytical Studies on a Streamlined Steel Box Girder, J. of Constructional Steel Research, Vol. 66, pp. 906-914.

14. Xu, C., Su, Q., Wu, C., Sugiura, k. (2011), Experimental Study on Double Composition Action in the Negative Flexural Region of Two-Span Continuous Composite Box Girder, J. of Constructional Steel Research, Vol. 67, pp. 16361648.

15. Hodson, D. J., Barr, P. J., and Halling, M. W. (2012), Live-Load Analysis of Post-tensioned Box Girder Bridges, J. of Bridge Engineering, 17(4), pp. 644651.

16. Lu, P. Xie, X., Shao, C., (2012), Experimental Study and Numerical Analysis of a Composite Bridge Structure, Construction and Building Materials, Vol. 30, pp. 695-705.

17. Guo, T. and Chen, Y. W. (2013). Fatigue Reliability Analysis of Steel Bridge Details Based on FieldMonitored Data and Linear Elastic Fracture 
Mechanics, Structures and Infrastructure Engineering, 9(5), pp. 496-505.

18. Kurian, B. and Menon, D. (2007), Estimation of Collapse Load of Single Cell Concrete Box-Girder Bridges, J. of Bridge Engineering, 12 (4), pp. 518526.

19. Vlazov, V. Z. (1965), "Thin-walled elastic beams" OTS61-11400, National Science Foundation, Washington, D.C.

20. Maisel, B. I. and Roll, F. (1974), "Methods of analysis and design of concrete box beams with side cantilevers", Tech. Rep. No. 42, Cement and Concrete Association, London.

21. Swann, R.A. (1972), A feature survey of concrete spine-beam bridges, Technical Rep. No. 42.469, Cement and Concrete Association, London.

22. Rasmussen, L. J., and Baker, G. (1999), "Large-scale experimental investigation of deformable RC box sections" J. Structural Engineering, 125(3), pp. 227235.

23. Loo, Y. C. and Cusens, A. R. (1978), The Finite Strip Method in Bridge Engineering, Viewpoint Publications, Cement and Concrete Association, Wexham Springs.

24. Lertsima, C., Chaisomphob, T., Yamaguchi, E., Sanguanmanasak, J., (2005), Deflection of Simply Supported Box Girder Including Effect of Shear Lag, Computer and Structures, Vol.84, pp. 11-18.

25. Halkude, S. A. and Akim, C. Y. (2012), Analysis of Straight and Skewed Box Girder Bridge by Finite Strip Method, International J. of Emerging Technology and Advanced Engineering, 2(11), pp. 191-198.

26. Cheung, Y.K. (1976), Finite Strip Method in Structural Analysis, $1^{\text {st }}$ ed., Pergamon Press, Oxford. 